Research

\title{
Bone marrow chimeric mice reveal a dual role for CD36 in Plasmodium berghei ANKA infection Margarida Cunha-Rodrigues ${ }^{1,2}$, Sílvia Portugal1,2, Maria Febbraio ${ }^{3}$ and Maria M Mota*1,2
}

Address: ${ }^{1}$ Unidade de Malária, Instituto de Medicina Molecular, Faculdade de Medicina da Universidade de Lisboa, Av. Prof. Egas Moniz, 1649028 Lisboa, Portugal, ${ }^{2}$ Instituto Gulbenkian de Ciência, 2781-156 Oeiras, Portugal and ${ }^{3}$ Cell Biology, Lerner Research Institute, Cleveland Clinic, Cleveland, Ohio, USA

Email: Margarida Cunha-Rodrigues - margaridacunha@fm.ul.pt; Sílvia Portugal - sportugal@fm.ul.pt; Maria Febbraio - febbram@ccf.org; Maria M Mota* - mmota@fm.ul.pt

* Corresponding author

Published: 16 March 2007

Malaria Journal 2007, 6:32 doi:10.1 186/1475-2875-6-32
Received: 23 November 2006

Accepted: 16 March 2007

This article is available from: http://www.malariajournal.com/content/6/I/32

(C) 2007 Cunha-Rodrigues et al; licensee BioMed Central Ltd.

This is an Open Access article distributed under the terms of the Creative Commons Attribution License (http://creativecommons.org/licenses/by/2.0), which permits unrestricted use, distribution, and reproduction in any medium, provided the original work is properly cited.

\begin{abstract}
Background: Adhesion of Plasmodium-infected red blood cells (iRBC) to different host cells, ranging from endothelial to red blood cells, is associated to malaria pathology. In vitro studies have shown the relevance of CD36 for adhesion phenotypes of Plasmodium falciparum iRBC such as sequestration, platelet mediated clumping and non-opsonic uptake of iRBC. Different adhesion phenotypes involve different host cells and are associated with different pathological outcomes of disease. Studies with different human populations with CD36 polymorphisms failed to attribute a clear role to CD36 expression in human malaria. Up to the present, no in vivo model has been available to study the relevance of different CD36 adhesion phenotypes to the pathological course of Plasmodium infection.
\end{abstract}

Methods: Using CD36-deficient mice and their control littermates, CD36 bone marrow chimeric mice, expressing CD36 exclusively in haematopoietic cells or in non-haematopoietic cells, were generated. Irradiated CD36-- and wild type mice were also reconstituted with syngeneic cells to control for the effects of irradiation. The reconstituted mice were infected with Plasmodium berghei ANKA and analysed for the development of blood parasitaemia and neurological symptoms.

Results: All mice reconstituted with syngeneic bone marrow cells as well as chimeric mice expressing CD36 exclusively in non-haematopoietic cells died from experimental cerebral malaria between day 6 and 12 after infection. A significant proportion of chimeric mice expressing CD36 only in haematopoietic cells did not die from cerebral malaria.

Conclusion: The analysis of bone marrow chimeric mice reveals a dual role of CD36 in P. berghei ANKA infection. Expression of CD36 in haematopoietic cells, most likely macrophages and dendritic cells, has a beneficial effect that is masked in normal mice by adverse effects of CD36 expression in non-haematopoietic cells, most likely endothelial cells. 


\section{Background}

Malaria is the consequence of Plasmodium infection that occurs in a variety of forms, affecting many organs, with different pathological and clinical features [1]. The mechanisms behind the pathogenesis of the various disease syndromes remain poorly understood. The interactions of infected red blood cells (iRBC) with various cells of the host (often referred to as adhesion phenotypes) are thought to be involved in several features of the disease. The accumulation of iRBC in the microvasculature of various organs is believed to protect the parasite from elimination by the spleen and to be a prominent cause of organ-specific malaria syndromes [2]. Non-opsonic phagocytosis is thought to eliminate parasites in a noninflammatory manner that is reminiscent of the removal of apoptototic cells [3-8]. Several host cells that are involved in iRBC adhesion phenotypes are also involved in general inflammation processes and immune responses of the host. CD36 is a multiligand scavenger receptor that is expressed by many of these cells such as endothelial cells, platelets, dendritic cells and macrophages [9], as well as on both erythroid precursors [10] and normal erythrocytes $[11,12]$. Adhesion phenotypes involving CD36 include iRBC binding to endothelial cells $[13,14]$ and platelet mediated clumping [15], both of which contribute to the occlusion of the microvasculature in target organs. Non-opsonic uptake of iRBC contributes to the clearance of parasites and modulation of phagocytic cells [3-8]. Thus, CD36 is involved in a variety of host-parasite interactions that may be protective and harmful to both the host and the parasite (reviewed in [8]). Moreover, studies attempting to associate severe malaria syndromes with CD36 polymorphisms in human populations have yielded conflicting results [16-18]. Thus, the role of CD36 in the pathology of human malaria remains elusive and CD36-mediated adhesion cannot be considered as a validated target for anti-malarial intervention.

In the present work, CD36 bone marrow chimeric mice were generated to dissect and measure the contribution of CD36 expression by resident cells versus its role in circulating cells to disease outcome. The exclusive expression of CD36 in haematopoietic cells resulted in 25\% protection from experimental cerebral malaria (ECM). In wild type mice this protective effect appears to be counteracted by CD36 expression in non-haematopoietic cells. These results indicate that, to be effective, agents that target CD36-binding for malaria intervention need to be celltype specific, a requirement that cannot readily be met by present day technologies of drug development.

\section{Methods \\ Mice, parasites and infection}

Seven to nine-week old male CD36-deficient mice (C57Bl/6 background) [19] and their wild type littermates were infected with fresh $10^{6}$ green fluorescent protein (GFP)-expressing Plasmodium berghei ANKA iRBCs [20] by intra-peritoneal (i.p.) injection, after one passage through mice infected from a frozen vial. Peripheral blood parasitaemia was determined by flow cytometry and expressed as percentage of infected red blood cells, as described elsewhere [20]. Mice were observed for cerebral complications, i.e ataxia, paralysis, deviation of the head and convulsions, coma and death.

\section{CD36 bone marrow chimeric mice}

CD36\% mice were lethally $\gamma$-irradiated (900 rads) and reconstituted with $\mathrm{CD} 36^{+/+}$bone marrow cells (CD36 $6^{+/+}$ into $\mathrm{CD} 36 \%$ chimeras) or $\mathrm{CD} 36 \%$ bone marrow cells $\left(\mathrm{CD} 36^{-/}\right.$into CD36+/+). Reverse chimeric mice were also created by lethally irradiating $\mathrm{CD} 36^{+/+}$mice and reconstituting them with either CD36\% $/$ CD $36 \%$ into CD $36^{+/+}$chimeras) or $\mathrm{CD} 36^{+/+}$bone marrow cells $\left(\mathrm{CD} 36^{+/+}\right.$into CD $36^{+/+}$chimeras). Bone marrow cells from donor mice $\left(6.5 \times 10^{6}\right)$ were injected into each recipient mouse through the retro-orbital venous plexus one to five hours after irradiation. Chimeric animals were allowed to recover for five weeks before infection was initiated as described above. Depletion of circulating cells and reconstitution with donor cells was confirmed in all chimeric mice by PCR of blood genomic DNA. Blood was collected from the tail and DNA extracted using QIAamp DNA Micro Kit (Qiagen). PCR was performed using PCR Master Mix (Promega kit) and a set of three primers that amplify sequence either from the wild type (600 bp) or knockout (750-800 bp) allele. The following oligonucleotides (5'3') were used for specific amplification: CAGCTCATACATTGCTGTTTATGCATG, GGTACAATCACAGTGTTTTCTACGTGG and CCGCTTCCTCGT GCTTTACGGTATC. Amplification program: $95^{\circ} 4 \mathrm{~min}-1$ cycle; $94^{\circ} 1 \mathrm{~min}$, $65^{\circ} 1 \mathrm{~min}, 72^{\circ} 2 \mathrm{~min}-30$ cycles; $4^{\circ} \infty$.

\section{Results and discussion}

CD36 is expressed by both haematopoietic and non-haematopoietic cells [9-12]. CD36 is not only an important mediator of microvessels obstruction by Plasmodium falciparum iRBC, but also required for the non-opsonic phagocytosis of different stages of $P$. falciparum iRBC $[4,5,21,22]$. No consensus has been reached regarding the role of CD36 in the development of severe malaria syndromes in humans $[8,23]$. Since rodent malaria iRBCs also bind CD36 [24,25], mouse models may be used to study the requirement of CD36 in various features of Plasmodium infection [26]. Like in humans, Plasmodium infection of mice results in different pathologies that depend on the genomes of both the parasite and the host $[26,27]$. 

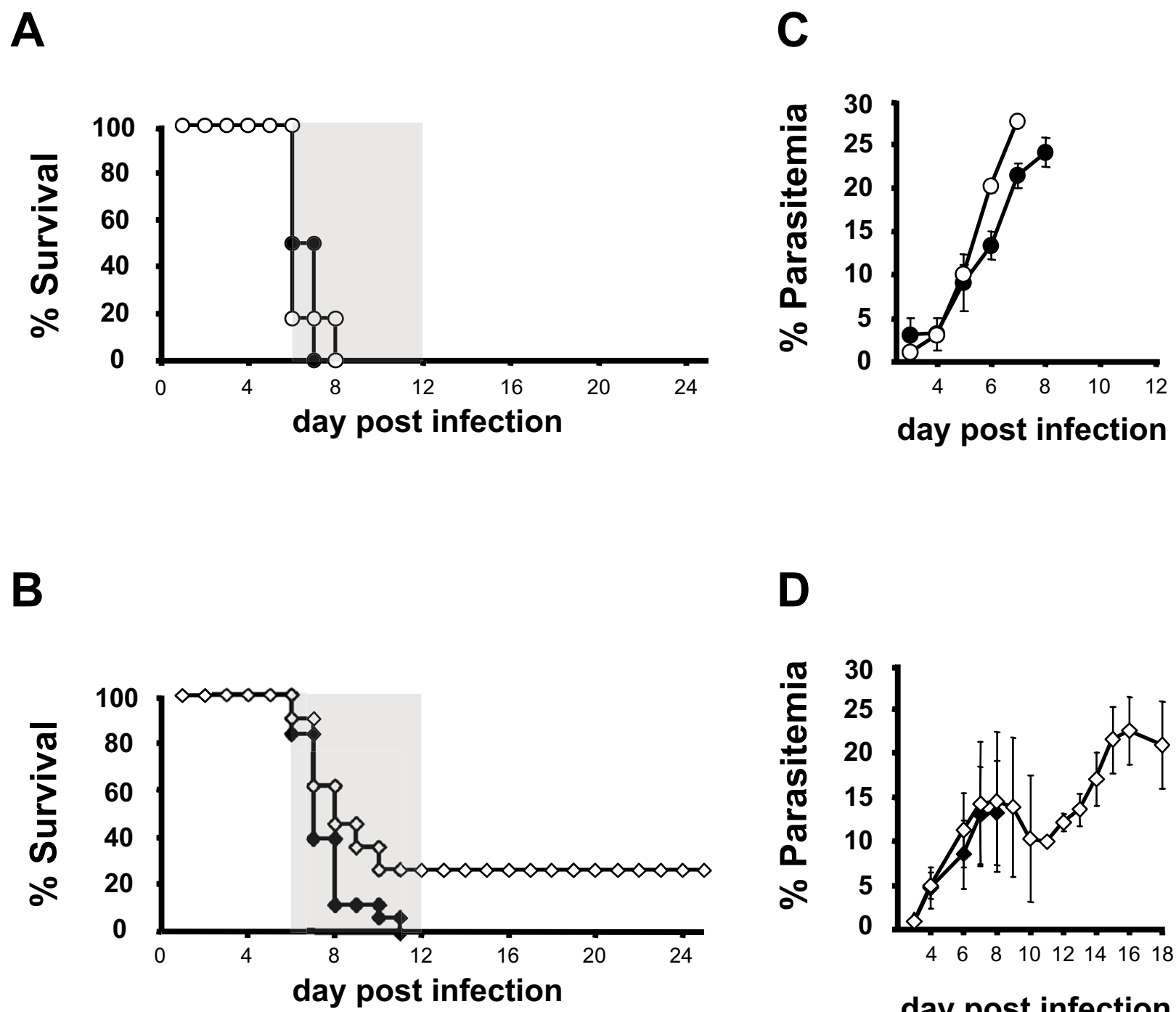

\section{day post infection}

Figure I

Bone marrow chimeric mice with CD36 expression confined to lethal radiation-sensitive cells are partially protected from CM. (A) Cumulative survival and parasitaemias $(C)$ of $C D 36^{+/+}$into $\mathrm{CD}^{+/+}(\mathrm{n}=\mathrm{II})$ and $\mathrm{CD} 36^{-/-}$into $\mathrm{CD}^{+16^{+/+}}$ $(n=I I)$ through the course of $P$. berghei ANKA infection. (B) Cumulative survival and parasitaemias (D) of CD36+/+ into CD36I- $(n=3 I)$ and CD36-/- into CD36-/- $(n=18)$ through the course of $P$. berghei ANKA infection. Survival curves represent the summary of four of independent experiments. Parasitaemia curves are from one representative experiment out of the four performed. In two independent experiments, CD36+/+bmCD36-/- and CD36-/-bm CD36+/+ were generated and infected at same

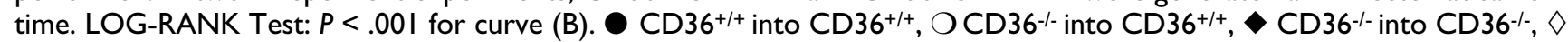
CD36+/+ into CD36-/. Gray area represents the time window for ECM development.

Previous work has shown that CD36 is essential for the accumulation of $P$. berghei ANKA iRBC in the lungs and adipose tissues, but has no role in the development of parasitaemia and the lethal course of ECM [25].

To further define the role of CD36 expression in circulating cells such as macrophages and DCs, CD36 chimeric mice were generated by bone marrow transplantation. To control for irradiation effects CD36\%-mice and wild-type mice were also reconstituted with syngeneic bone marrow cells. Five weeks after reconstitution, chimeras showed more than 90\% chimerism, as determined by blood genomic DNA PCR (data not shown). The four groups of reconstituted mice were then infected with $P$. berghei 
ANKA parasites that induce ECM in mice with the C57BL6 background. The two groups of mice reconstituted with syngeneic bone marrow cells (Figure $1 \mathrm{~A}$ and $1 \mathrm{~B}$ ) and CD $36^{-/}$into CD $36^{+/+}$chimeras (Figure $1 \mathrm{~A}$ ) died six to 12 days after infection with neurological symptoms like previously observed for non-irradiated CD $36 \%$ and wild type C57BL/6 mice. However, a significant proportion $(25.8 \pm$ $9.3 \%, \mathrm{n}=31$ ) of chimeras expressing CD36 exclusively in haematopoietic cells, but not in other cells $\left(\mathrm{CD} 36^{+/+}\right.$into CD36\% chimeras) did not develop ECM (Figure 1B). These mice survived ECM and died later with higher parasitaemias (Figure 1D). No differences were observed between each chimeric group and its syngenic control in the development of peripheral blood parasitaemia (Figure $1 \mathrm{C}$ and 1D). These findings suggest a small, but significant beneficial role for CD36 when expressed only in haematopoietic cells and an adverse effect when expressed elsewhere.

CD36-mediated adhesion phenotypes involving haematopoietic cells include non-opsonic phagoytosis of iRBC by macrophages and dendritic cells and platelet mediated clumping. The later contributes to the obstruction of the microvasculature $[15,28]$ and thus it is unlikely to be responsible for the beneficial effect of $\mathrm{CD} 36$ expression in haematopoietic cells that is apparent in the $\mathrm{CD} 6^{+/+}$into CD36\% chimeras. Whether additional abrogation of CD36 expression in platelets of CD $36^{+/+}$into CD $36^{-/}$chimeras would lead to a higher protection still remains to be elucidated.

The present study provides the first in vivo evidence, albeit indirect, that non-opsonic phagocytosis of iRBC by macrophages and dendritic cells may have a beneficial effect in malaria infections and reduce the risk of development of ECM. In non-chimeric animals, as it might be in humans, this beneficial effect of CD36 is apparently offset, by adverse effects of CD36 expression in non-haematopoietic cells, such as endothelial cells. Our results suggest that therapeutic effects could only be achieved by either up-regulating CD36 expression in macrophages and dendritic cells and/or by downregulating CD36 expression by endothelial cells. A recent study has shown that CD36 expression and phagocytosis of iRBC could be selectively up-regulated by agonists of the peroxisome proliferator activated receptor $\gamma$ (PPAR $\gamma$ ) such as troglitazone [29]. Such selective up-regulation of CD36 in macrophages and dendritic cells may shift the balance towards the beneficial effects of CD36. However, this approach is not likely to have a significant effect in endemic areas where the populations have developed anti-Plasmodium antibodies and are thus less dependent on non-opsonic phagocytosis.

\section{Conclusion}

Although clear differences between malaria infections in humans and mice exist, certain aspects of the infection are comparable [26]. CD36 expression and CD36-mediated adhesion of iRBCs to the microvasculature, for example, has been shown not only for $P$. falciparum, but also for the rodent parasites Plasmodium chabaudi [24] and P. berghei [25]. Studies on human populations polymorphisms for CD36 failed to define a clear role for CD36 in severe malaria syndromes [16-18]. The present study with bone marrow chimeric mice revealed both beneficial and adverse effects of CD36 in infections with $P$. berghei ANKA. Taken together with observations in humans, this study in mice indicates that CD36 is not a straightforward anti-malarial drug target and does not support further efforts to develop drugs that indiscriminately block all CD36 functions.

\section{Authors' contributions}

MCR performed all experimental work, with exception of mice genotyping, and participated both in the study design and manuscript drafting. SP performed mice genotyping, RNA extractions and helped on chimeric mice experiments. MF participated in the study design and manuscript drafting. MMM conceived the study and participated in its design and coordination as well as in manuscript drafting. MMM supervises MCR and SP. All authors read and approved the final manuscript.

\section{Acknowledgements}

We thank Werner Haas and Miguel Prudêncio for critically reading this manuscript and Nuno Sepúlveda for his help with the statistical analysis. This work was supported by Fundação para a Ciência e Tecnologia grant POCI/BIA-BCM/6I799/2004 to MMM. MCR and SP are supported by FCT Fellowships, SFRH/BD/8435/2002 and SFRH/BD/3 I523/2006 respectively. MMM is a Fellow of the EMBO YIP and is a Howard Hughes Medical Institute International Research Scholar.

\section{References}

I. Maitland K, Marsh K: Pathophysiology of severe malaria in children. Acta Trop 2004, 90:131-140.

2. Rasti N, Wahlgren M, Chen Q: Molecular aspects of malaria pathogenesis. FEMS Immunol Med Microbiol 2004, 41:9-26.

3. Platt N, da Silva RP, Gordon S: Recognizing death: the phagocytosis of apoptotic cells. Trends Cell Biol I998, 8:365-372.

4. Patel SN, Serghides L, Smith TG, Febbraio M, Silverstein RL, Kurtz TW, Pravenec M, Kain KC: CD36 mediates the phagocytosis of Plasmodium falciparum-infected erythrocytes by rodent macrophages. J Infect Dis 2004, I 89:204-2I3.

5. McGilvray ID, Serghides L, Kapus A, Rotstein OD, Kain KC: Nonopsonic monocyte/macrophage phagocytosis of Plasmodium falciparum-parasitized erythrocytes: a role for CD36 in malarial clearance. Blood 2000, 96:3231-3240.

6. Urban BC, Ferguson DJ, Pain A, Willcox N, Plebanski M, Austyn JM, Roberts DJ: Plasmodium falciparum-infected erythrocytes modulate the maturation of dendritic cells. Nature 1999, 400:73-77.

7. Urban BC, Roberts DJ: Malaria, monocytes, macrophages and myeloid dendritic cells: sticking of infected erythrocytes switches off host cells. Curr Opin Immunol 2002, 14:458-465.

8. Serghides L, Smith TG, Patel SN, Kain KC: CD36 and malaria: friends or foes? Trends Parasitol 2003, 19:46I-469. 
9. Febbraio M, Hajjar DP, Silverstein RL: CD36: a class B scavenger receptor involved in angiogenesis, atherosclerosis, inflammation, and lipid metabolism. J Clin Invest 200I, I08:785-79I.

10. Kieffer N, Bettaieb A, Legrand C, Coulombel L, Vainchenker W, Edelman L, Breton-Gorius J: Developmentally regulated expression of a $78 \mathrm{kDa}$ erythroblast membrane glycoprotein immunologically related to the platelet thrombospondin receptor. Biochem J 1989, 262:835-842.

II. Handunnetti SM, van Schravendijk MR, Hasler T, Barnwell JW, Greenwalt $\mathrm{DE}$, Howard RJ: Involvement of CD36 on erythrocytes as arosetting receptor for Plasmodium falciparum-infected erythrocytes. Blood 1992, 80:2097-2104.

12. van Schravendijk MR, Handunnetti SM, Barnwell JW, Howard RJ: Normal human erythrocytes express CD36, an adhesion molecule of monocytes, platelets, and endothelial cells. Blood 1992, 80:2105-2||4.

13. Ockenhouse CF, Tandon NN, Magowan C, Jamieson GA, Chulay JD: Identification of a platelet membrane glycoprotein as a falciparum malaria sequestration receptor. Science 1989, 243:|469-|47|.

14. MacPherson GG, Warrell MJ, White NJ, Looareesuwan S, Warrell DA: Human cerebral malaria. A quantitative ultrastructura analysis of parasitized erythrocyte sequestration. Am J Pathol I 985, I | 9:385-40 I.

15. Pain A, Ferguson DJ, Kai O, Urban BC, Lowe B, Marsh K, Roberts DJ: Platelet-mediated clumping of Plasmodiumfalciparuminfected erythrocytes is a common adhesive phenotype and is associated with severe malaria. Proc Natl Acad Sci USA 200I, 98: $1805-1810$

16. Aitman TJ, Cooper LD, Norsworthy PJ, Wahid FN, Gray JK, Curtis BR, McKeigue PM, Kwiatkowski D, Greenwood BM, Snow RW, Hill AV, Scott J: Malaria susceptibility and CD36 mutation. Nature 2000, 405: $1015-1016$.

17. Omi K, Ohashi J, Patarapotikul J, Hananantachai H, Naka I, Looareesuwan S, Tokunaga K: CD36 polymorphism is associated with protection from cerebral malaria. Am J Hum Genet 2003, 72:364-374.

18. Newbold C, Craig A, Kyes S, Rowe A, Fernandez-Reyes D, Fagan T: Cytoadherence, pathogenesis and the infected red cell surfacein Plasmodium falciparum. Int J Parasitol 1999, 29:927-937.

19. Febbraio M, Abumrad NA, Hajjar DP, Sharma K, Cheng W, Pearce SF, Silverstein RL: A null mutation in murine CD36 reveals an important role in fatty acid and lipoprotein metabolism. J Biol Chem 1999, 274:19055-19062.

20. Franke-Fayard B, Trueman H, Ramesar J, Mendoza J, van der Keur M, van der Linden R, Sinden RE, Waters AP, Janse CJ: A Plasmodium berghei reference line that constitutivelyexpresses GFP at a high level throughout the complete life cycle. Mol Biochem Parasitol 2004, 137:23-33.

21. Smith TG, Serghides L, Patel SN, Febbraio M, Silverstein RL, Kain KC: CD36-mediated nonopsonic phagocytosis of erythrocytesinfected with stage I and IIA gametocytes of Plasmodium falciparum. Infect Immun 2003, 71:393-400.

22. Ayi K, Patel SN, Serghides L, Smith TG, Kain KC: Nonopsonic phagocytosis of erythrocytes infected with ring-stage Plasmodium falciparum. Infect Immun 2005, 73:2559-2563.

23. Cunha-Rodrigues M, Prudencio M, Mota MM, Haas W: Antimalarial drugs - host targets (re)visited. Biotechnol J 2006, I:32 I-332.

24. Mota MM, Jarra W, Hirst E, Patnaik PK, Holder AA: Plasmodium chabaudi-infected erythrocytes adhere to CD36 and bind to microvascular endothelial cells in an organ-specific way. Infect Immun 2000, 68:4I35-4I44.

25. Franke-Fayard B, Janse C], Cunha-Rodrigues $M$, Ramesar J, Buscher $P$, Que I, Lowik C, Voshol PJ, den Boer MA, van Duinen SG, Febbraio M, Mota MM, Waters AP: Murine malaria parasite sequestration: CD36 is the major receptor, but cerebral pathology is unlinked to sequestration. Proc Natl Acad Sci USA 2005, 102: I 4 468-II 473

26. de Souza JB, Riley EM: Cerebral malaria: the contribution of studies in animal models to our understanding of immunopathogenesis. Microbes Infect 2002, 4:29I-300.

27. Schofield L, Grau GE: Immunological processes in malaria pathogenesis. Nat Rev Immunol 2005, 5:722-735.

28. Wassmer SC, Lepolard C, Traore B, Pouvelle B, Gysin J, Grau GE: Platelets reorient Plasmodium falciparum-infected erythro- cyte cytoadhesion to activated endothelial cells. I Infect Dis 2004, I89:180-189.

29. Serghides L, Kain KC: Peroxisome proliferator-activatedreceptor gamma and retinoid $X$ receptor agonists have minimal effectson the interaction of endothelial cells with Plasmodium falciparum-infected erythrocytes. Infect Immun 2005, 73: $1209-1213$.
Publish with Biomed Central and every scientist can read your work free of charge

"BioMed Central will be the most significant development for disseminating the results of biomedical research in our lifetime. "

Sir Paul Nurse, Cancer Research UK

Your research papers will be:

- available free of charge to the entire biomedical community

- peer reviewed and published immediately upon acceptance

- cited in PubMed and archived on PubMed Central

- yours - you keep the copyright

Submit your manuscript here:

http://www.biomedcentral.com/info/publishing_adv.asp 